\title{
The Nigerian Petroleum Industry Bill: An Evaluation of the Effect of the Proposed Fiscal Terms on Investment in the Upstream Sector
}

\author{
SANI SAIDU ${ }^{1, *}$, ABDEL RASHEED MOHAMMED $^{2}$ \\ ${ }^{1}$ Aberdeen Business School, Robert Gordon University, United Kingdom \\ ${ }^{2}$ Dundee Business School, Abertay University, Dundee, United Kingdom \\ *Corresponding author: S.SAIDU@RGU.AC.UK
}

Received June 08, 2014; Revised June 30, 2014; Accepted July 10, 2014

\begin{abstract}
The international oil companies (IOCs) in Nigeria have expressed concern over the federal government's intention to change the laws governing the oil and gas industry including the fiscal terms. They claim that the proposed fiscal terms will affect their bottom line and trigger uncertainties in their investments in the upstream sector. Therefore, this research was conducted with the aim of evaluating the effect of the proposed fiscal terms on upstream petroleum investment, in which the IOCs are involved. Hence, document analysis and economic indicators of investment profitability were employed in the conduct of this study. The results show that, even though petroleum projects remain profitable under the proposed fiscal terms, the lack of fiscal stability will negatively affect investment at least in the short term. This study should be of assistance to policy makers, legislators, industry regulators and other stakeholders to better appreciate the implications of the PIB-proposed fiscal system and terms on investment in the upstream petroleum sector.
\end{abstract}

Keywords: Nigerian petroleum industry bill, upstream sector, the international oil companies

Cite This Article: SANI SAIDU, and ABDEL RASHEED MOHAMMED, "The Nigerian Petroleum Industry Bill: An Evaluation of the Effect of the Proposed Fiscal Terms on Investment in the Upstream Sector." Journal of Business and Management Sciences, vol. 2, no. 2 (2014): 45-57. doi: 10.12691/jbms-2-2-3.

\section{Background of the Study}

The commercial discovery of oil at Oloibiri in 1956 by Shell-BP effectively marked the beginning of petroleum operations in Nigeria (Ameh, 2006). Following shell's success, by 1965, more International Oil Companies (IOCs) including Gulf oil, Texaco, Elf, Mobil and Agip were involved in petroleum exploration and production (E\&P) operations in Nigeria. As such, the IOCs dominated the Nigerian oil industry for decades. The Nigerian economy has over time become largely dependent on petroleum. Petroleum accounts for about one-third of the country's Gross Domestic Product (GDP); $76 \%$ of government revenue; and $95 \%$ of the foreign exchange earnings. Hence, the government has continued to exercise increasing control on the country's petroleum operations with the latest being provided in the Petroleum Industry Bill (PIB). The PIB proposes a number of reforms in the petroleum industry. The current laws include the Petroleum Act of 1969; Petroleum Profit Tax Act of 1959; and Nigerian National Petroleum Corporation (NNPC) Act 1977 among other legislations (PIB, 2008). The proposed laws involve an overhaul of the existing petroleum laws including the fiscal system. This is intended at encouraging local participation in the petroleum industry and maximizing government take in giant fields among other things (Lukman, 2009).However, some IOCs have expressed reservations over the proposed laws; for example, the following words of the Managing Director of Shell Nigeria (SPDC) succinctly sum up some of these reservations: "The PIB proposes multiple increased royalties and fiscal terms that will slow down new investments in deep water considerably. It will also exclude a number of legitimate costs from being recovered. Uncertainties around these issues are already stalling development of major discovered resources and discouraging companies from undertaking the aggressive exploration programmes they launched under the 1993 production Sharing Contracts (PSC's)” (BusinessDay, 2009).These types of reservation by highly placed individuals and alleged corruption in the Nigerian petroleum industry caused concern amongst stakeholders as to what is holding the passage of the bill (Kalejaye, 2014). In fact, Kalejaye (2014) opined that the non-passage of the Petroleum Industry Billin 2014, almost 6 years of its initial proposal in 2007 by National Assembly has been viewed by industry players as a major threat to the growth and development of the Nigeria Content Act. Of course, Indigenous players believed that the unending delay of the bill has stalled potential investment climate and slowed the growth in Nigeria's oil and gas sector. Therefore, considering the strategic importance of IOCs in the Nigerian oil and gas industry coupled with the paucity of domestic technical know-how, lack of finance, and the 
extent of reliance of the Nigerian economy on oil revenue, it becomes necessary to evaluate the extent to which investment in the upstream oil and gas sector would be affected by the PIB-proposed fiscal terms. In this regard, the paper has been divided into five sections. In section 2 , the dynamics of petroleum investment and fiscal systems are discussed. Section 3 briefed research designed adopted in the research. Data analysis and discussion are presented in section 4. Finally, Section 4 concludes the research.

\subsection{Research Questions}

Arising from the above, this research sets out to address the main question "How would the PIB-proposed fiscal terms and design affect upstream investment in the Nigerian petroleum industry?" In order to answer this question adequately, two specific objectives were developed as presented below:

i. To assess whether the fiscal system under the PIB terms is designed in a way that will attract IOC investment.

ii. To find out if the economic indicators of project profitability under the PIB-proposed terms are positive or profitable.

\section{The Dynamics of Petroleum Investment and Fiscal Systems}

The activities in the oil and gas industry are characterized by huge capital investments; high level of expertise; high physical, political, and socio-economic risks (Pongsiri, 2004). Due to the risks involved, coupled with the difficulties in gaining access to risk capital, and dearth of technical expertise required for Exploration and Production (E\&P), developing countries usually grant rights to IOCs (who have the capital, technology, and expertise) to explore, develop and produce their oil and gas resources (Brock et al. 2007 andPongsiri, 2004). In the meantime, however, the extent to which a country attracts investment in the oil and gas industry is determined by many factors such as: (i) geopolitical stability and government policy; (ii) size and quality of reserves; (iii) capability of NOC; (iv) demand pessimism and oil prices and (v) fiscal systems. Most IOCs give more emphasis to fiscal systems than other determining factors. Hence, briefly discussed in sub-sections below:

\subsection{Fiscal Systems}

Petroleum rights in most Host Countries (HCs) are vested in the state. Hence, the governments in these states are automatically entitled to the landlord's share of oil production (Kemp, 1992). However, because of the risks involved in oil operations, governments in HCs (especially developing countries) usually arrange with IOCs to explore, develop and produce their oil and gas (Brock et al., 2007; Pongsiri, 2004). As a result, a significant factor in international oil and gas accounting is how the host countries and the IOCs share the proceeds from such operations. Therefore, one of the most important aspects of the arrangements with IOCs is the fiscal system, which details the sharing arrangement on how oil and gas production/revenues would be allocated amongst the venture parties (Brock, et al., 2007). Over the years, governments of HCs have introduced fiscal arrangements to ensure that they benefit from the economic rents (Kemp, 1992). Economic rents arising from mineral exploitation have usually been seen as suitable base for taxation so that their collection does not distort the investment decisions (Kemp, 1992). That is, if fiscal systems are accurately directed at economic rents, investment in E\&P should not be affected. However, majority of fiscal systems are not only directed at economic rents (Kemp, 1992). As a result, the effect of a fiscal system may not be very obvious until a detailed analysis is undertaken to ascertain the extent of the impact. In general, the fiscal system covers fiscal elements such as: (i) bonus payment to the $\mathrm{HC}$; (ii) royalty payment to the HC; (iii) investment cost recovery; (iv) profit sharing between HC and IOC; (v) taxation by the HC; and (vi) infrastructural development for the HC (Brock et al. 2007). These elements, which are commonly found in fiscal systems around the world, are discussed below:

\subsubsection{Bonus Payment to Host Country}

A typical petroleum contract may require the payment of one type of bonus or another: Signature bonus refers to the payment made upon the conclusion of contract signing; discovery bonus is paid when oil discovery is made while production bonus is paid when certain levels of production are achieved (Kaiser and Pulsipher, 2004). Whereas the signature and discovery bonuses are usually one-off payments, production bonuses are paid more than ones. Typically, HCs require an up-front lump-sum bonus payment upon the execution of E\&P agreements. Alternatively, some HCs sometimes require a reduced upfront payment of bonus with subsequent periodic bonus payments in the form of discovery and/or production bonuses (Brock et al. 2007). This is to allow the IOCs to invest more into exploration and development activities.

\subsubsection{Royalties' Payment to the Host Country}

Royalties are usually percentage-charges on production. The rates and formulae for determining the royalties differ from country to country (Johnston, 2003). The royalties rates could be varied in line with the grades, quantity, price and/or reservoir-depth of the oil and gas produced, applying sliding scale percentages based on the quantities produced, or arrangements based on the units of production. However, the unit of production method is the commonly used approach (Brock et al., 2007). Meanwhile, royalty payment is applicable to all forms of fiscal systems.

\subsubsection{Cost Recovery by International Oil Companies}

HCs usually require IOCs to bear the entire costs of exploration and sometimes development (Pongsiri, 2004). Hence, Production Sharing Contracts (PSCs) usually assign a substantial part of early oil and gas proceeds or production to the IOCs towards cost recovery, usually called the cost oil. The amount of costs recoverable for a particular period is however dependent on the individual contracts. In any case however, operating costs are generally recoverable in the period incurred, as well as amortization of accumulated capital costs (Brock et al.2007). The cost recoveries are typically restricted to production from discrete fields (ring-fencing), unless if the 
government relaxes this requirement in order to boost investment in the industry.

\subsubsection{Profit Sharing between Host Countries and Interntional Oil Companies}

In a PSC, the HC and the IOCs, based on the agreed sharing percentages, share the residual production after deducting the royalty oil and cost oil from total production. On sharing the profit oil, what is accruing to the IOC represents the contractors' take (Johnston, 2003). For Joint Venture Agreement (JV), residual production after deducting royalties, operating costs, depreciation, depletion and amortization (DD\&A) and intangible drilling costs, is shared by the venture partners (Johnston, 2003).

\subsubsection{Taxation by Host Countries}

Another aspect of the government take is income taxation. Other forms of taxation such as petroleum revenue tax (U.K. and Australia), and value-added-tax (VAT) apply in some HCs. Tax systems differ around the world: whereas some countries have formal petroleum income tax legislations, some others apply tax rules in individual E\&P contracts (Brock et al. 2007). Also, determining the gross taxable profit could sometimes be difficult depending on the existence of domestic market obligation, and/or the use of free market prices or application of posted prices. Further, the type of allowable deductions against income differs between countries; for example, countries defer on the treatment of E\&P contract negotiation (preliminary) costs, home country costs, affiliates' costs, and all costs paid to related parties. Moreover, while debt finance may be important for at least the development stage of the E\&P operations, some HCs disallow interest payments outside their territories. However, royalties and costs recovered whenever reimbursements are made are typically treated as deductible.

\subsection{Infrastructural Development for Hcs}

Some HCs do require IOCs to provide certain infrastructure and some industrial investment including training and employment of local personnel as part of the contract. While some HCs may require the infrastructure at the earliest stage of the contract, some insist on when commerciality is achieved (Brock et al. 2007). The infrastructure often includes construction of roads, utilities, housing, hospitals, schools and some facilities in host communities. For accounting purposes, the costs incurred are classified according to the nature of the expenditure: Costs that relate to acquisition, exploration, development and/or production are accounted for accordingly, while costs outside the normal E\&P classifications (e.g. building local hospital) are expensed in the period incurred.

\subsection{Stability in Relation to Government Policies}

Stability in government policies refers to a setting where frequent or arbitrary changes to the fiscal system is discouraged (Okobi, 2009). That is, a stable system is that which relatively remains materially unchanged or minimally altered over long period of time. Stability of government policy determines how secured a project is from arbitrary alterations to tax burdens. It determines the extent of the investors' confidence in an investment.

A more stable system provides greater certainty of projects anticipated cash flow than a less stable one (Akhigbe, 2008). Hence, past record of a country's fiscal stability is of immense importance for upstream petroleum investment decision making. Therefore, an assurance against arbitrary alterations to fiscal systems will constitute a great incentive for investors.

\subsection{Fiscal Flexibility}

Fiscal flexibility refers to the extent of responsiveness of the system to potential short-term economic realities (Faruque, 2005). That is, flexibility refers to sensitivity of the fiscal system to changing conditions in the industry. Conditions such as production rates, water depth, oil/gas ratio, cumulative production and price shocks associated with oil and gas, which could render a supposedly profitable project uneconomic, makes the use of flexible fiscal system more important (Akhigbe, 2008).

Sliding scale terms are often used to create flexible fiscal systems where a progressively lower profit oil share is assigned to the contractor as production increases (Johnston, 2003) or as prices increase. According to the prevailing conditions, terms such as cost recovery, profit oil, and royalties could be subjected to sliding scales. Meanwhile, the use of sliding scale provides for an equitable fiscal arrangement for $\mathrm{HC}$ and IOC to develop large and marginal oil fields (Johnston, 2003). Furthermore, provisions for renegotiation of contract terms also constitute a great incentive for the IOCs (Faruque, 2005).

\subsection{Fiscal Neutrality}

A neutral petroleum fiscal system refers to that in which the taxes/levies do not materially change the investors' view of which project is viable (Okobi, 2009). That is, a neutral system only taxes/charges the economic rent/profit; it does not concentrate taxes/levies on revenue. A tax charged on the profit of an investor does not impact the investor's investment or production decision. Hence, such systems are said to be neutral and efficient. A neutral system is paramount in aligning the interests of HCs and IOCs in a petroleum contract.

Fiscal neutrality of a system is measured based on how taxes and levies impact the behavior of investors (positive/negative) or whether the taxes are revenue-based or profit-based (Faruque, 2005). Generally, profit-based tax systems are said to be neutral. Revenue-based tax systems present an additional economic uncertainty as it could give rise to an effective tax rate of more than $100 \%$ (Brock et al, 2007). Therefore, the extent of fiscal neutrality is an important pointer to the attractiveness of a country to E\&P investment.

\subsection{The Take}

The governments or contractors take gives a fast yardstick for comparing fiscal systems (Johnston, 2003). The timing of government-take could be front-end or back-end loaded (Akhigbe, 2008). Front-end-loaded system indicate a system where government levies/taxes 
are skewed to dominate at the onset of production while in the back-end-loaded system, government levies/taxes are more at the onset of project profitability. The front-end system will not be attractive to investors because it is not neutral, reduces the project's Net Present Value (NPV) and shifts the project risks more towards them. The host government tries to avoid the back-end system because it tilts the project risks more towards it (Akigbe, 2008). Hence, investors would be more attracted to a system that improves their NPV and upholds mutual commitment to project risks.

Further, the relationship of the government-take and profitability could be progressive or regressive (Johnston, 2003). In a regressive system, the proportion of government-take decreases with increased project profitability (Kaiser and Pulsipher, 2004). A regressive system gives rise to an inverse relationship between project profitability and government-take. Therefore, IOCs who operate giant oil fields will enjoy bigger take when profitability increases at the expense of the government while the operators of marginal fields will continue to record reduced share of take for every price increase. This makes the regressive system very unfair and encourages early abandonment of oil fields (Abdulkarim, 2009). On the other hand, in a progressive system, the government-take and project profitability move in the same direction (Abdulkarim, 2009). That is, governmenttake increases with increased project profitability and vice versa. It is more flexible, fairer and more advantageous to government, IOC, highly profitable and marginal fields (Johnston, 2003).

\subsection{Petroleum Fiscal Systems and Upstream Investment}

The economics of offshore oil investment projects and PSCs in Nigeria using the meta-modeling method concluded that fiscal terms' impact on investment were not as severe compared to prevailing environmental factors and oil prices (Adenikinju and Oderinde (n.d.)). Accordingly, Fattouh and Darbouche (2010), in the review of foreign investment in changing oil market conditions in North Africa revealed that oil prices and country specific factors (size and quality of reserves, domestic politics, NOC capability and sanctions) impact investment more than fiscal terms; Algeria and Libya (despite tightening their economic fiscal terms) attracted more investment in the oil sector than Egypt and Sudan who had relatively more friendly economic fiscal terms. That is, IOCs may prefer a HC with a tight fiscal regime but whose business and geopolitical environment is very conducive than a HC with an attractive fiscal regime and turbulent business environment. Therefore, a mere alteration in a HCs' fiscal regime may not necessarily preclude its investment potentials.

However, Iledare (2004) used the discounted cash flow model on a hypothetical oil field in analyzing the impact of petroleum fiscal arrangements and contract terms on petroleum E\&P economics. Findings from this research suggests that government participation in E\&P operations through JV neither maximizes the fair value of oil and gas resources received by government nor optimize the returns of the IOCs. Evidence also suggests that under the general and analogous fiscal terms, the PSC system can be more attractive to IOCs than the JV system (Iledare, 2004). In the study of the impact of petroleum fiscal systems on offshore E \& P project economics and the take statistics, Iledare and Kaiser (2006) used the meta-modeling approach to analyze the PSC fiscal system and discovered that contractor take increases with increase in oil prices and profit oil but falls with increase in royalties and taxes. Also the present values of projects increase with increase in price and cost oil, and decrease with increase in tax and discounting factor. Furthermore, adopting the metamodeling analysis, Kaiser and Pulsipher (2004) studied the impact of concessionary and contractual fiscal systems on economics of offshore E\&P projects. The result is similar to the conclusion of Iledare and Kaiser (2006) except for the concessionary fiscal system (general JV form) where results show that the impact of a $1 \%$ increase in royalty rate on present value, rate of return, and take is slightly more than a $1 \%$ increase in the tax rate (Kaiser and Pulsipher, 2004). It could therefore be inferred from the foregoing studies that, all things being equal, the IOCs will generally prefer the PSC over the JV fiscal arrangements, and will also try to resist any increases in royalties and taxes since they impact their bottom line. However, increase in royalties impacts more than taxes.

In addition, Kemp (1992) made a comparative study of oil and gas development risk and fiscal regimes in the UK, Norway, Denmark and Netherlands using the financial modeling method. The UK system was found to be automatically progressive in respect of development costs and oil prices; the government take is generally tolerable and not likely to discourage new development investment. The Norway system produced a significant amount of government take; it is regressive in PV terms if $10 \%$ real discount rate is applied; in an unfavorable combination of development costs and prices of oil, development could be discouraged; and the participation of the state reduces the investment potential. The system in Denmark was found to be progressive in current money terms for changes in oil prices and development costs. In PV terms, it is broadly proportionate given the same costs conditions; higher government-take than in the UK, but could only inhibit investment under adverse combination of costs and oil prices. Finally for the Netherlands, Kemp concluded that the system is moderately progressive in nominal terms, but regressive in PV terms. Therefore, the structure of the fiscal system is equally an important consideration for investment purposes. A system that is progressive no matter how tight it may be could be more attractive to the regressive one. Issues of fiscal structure include stability, flexibility, neutrality, and front-end loaded or back-end loaded fiscal system.

From the foregoing studies, it could be inferred that fiscal systems (R/T, JV, PSC, SC,) and terms (royalties, taxes, bonuses, profit sharing, cost recovery, etc) impact the take (government and contractor) depending on how attractive it is. Some of what determine the attractiveness of the fiscal system includes its stability, flexibility, neutrality and the take. However, the profitability or otherwise of fiscal systems are not the only determinants of investment in the petroleum industry of a country. Nevertheless, they constitute an ideal pointer to an industry's potentials; many of the researches (Iledare 2004; Kaiser and Pulsipher, 2004; Kempt, 1992) reveal a strong 
link between the fiscal system and the level of investment in exploration and development.

In general, the foregoing has addressed the dynamics of petroleum fiscal systems and how they affect upstream investment. Further, it was clarified that in spite of the seeming impact of fiscal systems on petroleum investment, the impact may not be readily visible without in-depth study. Further, the rent-seeking attitude of HCs and IOCs which has over time given rise to changes in fiscal systems by HCs and which IOCs usually try to resist was addressed. The IOCs sometimes resist such changes in order to protect their rent-seeking advantage. Therefore, the claims of investment withdrawal by IOCs in respect of changes to fiscal systems, even though important, may be debatable after all.

\section{Research Design}

Data were collected from secondary sources while document review and investment appraisal techniques were used in analyzing the data. Arising from the research questions stated in Section 1.3, document analysis and economic indicators of investment profitability were employed in providing answers to the questions. For the independent variables, fiscal stability, flexibility, neutrality and take, document analysis was employed in carrying out the analysis. Conclusion from past studies and theoretical background of good petroleum fiscal system-design were used as the basis for the analysis. Past studies (Akhigbe, 2008; Brock et al. 2007; Faruque, 2005; Johnston 2003; Kaiser and Pulsipher, 2004; Okobi, 2009) identified what a stable, flexible, and neutral fiscal system is and hence, the researcher utilised these conclusions to establish how investment in upstream petroleum sector would be impacted. The documents reviewed here include the Petroleum Industry Bill (PIB), the petroleum Act 1969, petroleum profit tax Act 1959, and keynote address by the minister of petroleum resources on the PIB.

\subsection{Economic Indicators of Investment Profitability}

The modern methods utilised in carrying out the data analysis in this research are the cash flow, NPV, and IRR.In the case of Net Cash Flow (NCF), the model states that cash flow of an investment is the gross revenue received less all the expenses during a given period, usually a year, over the life of the project (Kaiser and Pulsipher, 2004). Therefore, the after-tax net cash flow of an oil field in year $t$ for concessionary and contractual fiscal regimes is respectively computed as in equations (1) and (2) below:

$$
\begin{aligned}
N C F_{t}= & G R_{t}-R O Y_{t}-C A P E X_{t}-O P E X_{t}-T A X_{t} \\
N C F_{t}= & G R_{t}-R O Y_{t}-C A P E X_{t}-O P E X_{t} \\
& - \text { BONUS }_{t}-P O / G_{t}-T A X_{t}-O T H E R_{t}
\end{aligned}
$$

Where,

$\boldsymbol{N C F t}=$ After-tax net cash flow in year $t$; $\boldsymbol{G R t}=$ Gross revenues in year $t ; \boldsymbol{R O Y t}=$ Total royalties paid in year $t$;

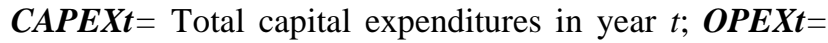
Total operating expenditures in year $t$; BONUSt= Bonus paid in year $t ; \boldsymbol{P O} / \mathbf{G t}=$ Government profit oil in year $t$; TAXt $=$ Total taxes paid in year $t$; OTHERt $=$ Other costs paid in year $t$.

The after tax net cash flow associated with field $J$ for its entire economic lifeis denoted as

$$
N C F(J)=\left(N C F_{1}, N C F_{2}, \ldots, N C F_{k}\right)
$$

It is assumed to begin in year one $(t=1)$ and run for the expected economic life of the field terminating at $t=k$.

Under the cash flow method, for a project to be acceptable, the cash flow must be positive. That is, the undiscounted income must exceed the expenses; else, the project is not viable.

Secondly, Net Present Value (NPV) and Internal Rate of Return (IRR)

The NPV and IRR assess whether the revenues generated by the project cover the expenditures and capital investment and the return on capital is consistent with the risk associated with the project and the strategic objectives of the corporation, taking into consideration the time value of money. The NPV provides an assessment of the project's absolute net worth to the contractor, while the IRR is a relative measure that is utilized in order to ascertain which projects should be chosen in order to optimize the benefits accruing from capital funds (Kaiser and Pulsipher, 2004). Meanwhile, a combination of these indicators is often necessary for adequate evaluation of an investment's economic viability. For field $J$, the present value and internal rate of return of the cash flow vector $N C F(J)$ is computed as:

$$
P V(J)=\sum_{t-1}^{k} \frac{N C F}{(1+D)^{t-1}}
$$

For a project to be accepted, the NPV must be positive; where there are more than one projects with positive NPV, the one with the highest NPV becomes more acceptable.

$$
\operatorname{IRR}(J)=\{D \mid P V(J)=0\}
$$

Where,

$\mathbf{D}=$ discount rate that equates the PV of the project to zero.

Any project that yields an IRR greater than the cost of capital is viable; where more than one project have their IRR greater than the cost of capital; the project with the highest IRR becomes the most preferable.

\section{Data Analysis and Discussion}

As earlier outlined the analysis of this research was based on deepwater PSC fiscal arrangements. This is because the deepwater production accounts for about onethird of Nigeria's oil production (Financial Times, 2010). Also, IOCs reservations concerning the PIB are more specifically directed at deepwater/frontier operations. Further, the analysis and discussions were focused on only oil production. Gas was not covered because the PIB proposes separate licenses for the two. The document analysis data were mainly derived from the PIB, PPT Act, NNPC and World Bank documents, while data for the economic analysis of net cash flow (NCF), NPV, PI and IRR were largely hypothetical. Therefore, it becomes imperative that the assumptions under which the hypothetical data were selected be justified. This is to 
ensure that the data, even though hypothetical, do conform to the theoretical and/or empirical realities of the issues under investigation. Therefore, this section discusses the assumptions for data selection and their justification. The assumptions were basically made on some input parameters which include the following; (i) oil fields, recoverable reserves and production; (ii) oil prices; (iii) capital (CAPEX) and operating (OPEX) expenses; (iv) IOC profit-oil split; (v) discount rate; and (vi) rentals

\subsection{The Petroleum Industry Bill (PIB)}

The PIB 2008 is an omnibus reform proposal which aims to establish legal, institutional and regulatory framework for the Nigerian petroleum industry (PIB, 2008), which the executive forwarded to the national assembly for passing into law (Lukman, 2009). The original PIB was a consolidation of the myriad of legislations governing the petroleum industry with mild changes to the existing fiscal system (Addax Petroleum, 2009).
However, the legislative and public-hearing debate gave rise to some sweeping changes to the PIB as proposed by the executive, including the fiscal provisions. Consequently, the changes, especially in the fiscal provisions, have elicited criticisms from IOCs, who claim that the changes will impact on their bottom line. Therefore, the updated version of the PIB which is materially different from both the original PIB, and the existing fiscal system, is the subject, and forms the basis for the analysis.

\subsubsection{Fields, Recoverable Reserves and Production}

In 1993, deepwater/frontier offshore oil blocks of water depth between 200metres and 3000metres were awarded to some domestic companies and IOCs in Nigeria under PSC arrangement. The E\&P operations on these blocks commenced in 1995 and by 2005, some were already producing. The main producing deepwater oil fields in Nigeria as at today are as presented in table 5.1 below:

Table 5.1. MAIN DEEPWATER PRODUCING OIL FIELDS IN NIGERIA

\begin{tabular}{|c|c|c|c|c|}
\hline S/N & FIELD NAMES & YEAR OF FIRST OIL & $\begin{array}{c}\text { ESTIMATED RECOVERABLE } \\
\text { RESERVE (BARRELS) }\end{array}$ & $600 \mathrm{million}$ \\
\hline 1 & Bonga & 2005 & $1000 \mathrm{billion}$ & 225,000 \\
\hline 2 & Erha\&Erha North & 2006 & $800 \mathrm{million}$ & 190,000 \\
\hline 3 & Agbami & 2008 & $620 \mathrm{million}$ & 250,000 \\
\hline 4 & Akpo & 2009 & 175,000 \\
\hline
\end{tabular}

Source: Consultancy Africa Intelligence, 2010/Rigzone, 2006

It has been earlier established in section 2.2.3 that, all things being equal, bigger oil fields are more profitable than smaller fields. Therefore, the researcher assumed a Nigerian deepwater oil field of a conservative reserves figure of 600 million barrels. This figure approximates the size of the smaller fields; such that if the smaller fields are profitable we can conclude the bigger ones are, too.

In the same vein, since higher production figures are more desirable for better profitability, a conservative peak production figure of 150,000 barrels was assumed in this study. Moreover, being frontier/new fields, there is no historical field life for Nigerian deepwater fields. However, a study of 568 deepwater oil field statistics reveals that the average life of a deepwater oil field is between 11-15 years (GersonLehrman Group, 2010). Hence, field life of 15 years was assumed for this model with peak production in the third year after production through the eight year, followed by an exponential production decline rate of $15 \%$ per annum over the remaining life of the field.

\subsubsection{Oil Price}

Considering the importance of oil prices in determining the profitability of oil fields, the profitability of oil projects is often threatened by low oil prices. Hence, the researcher employs three different price scenarios: low, medium and high prices; using the same production levels to test the profitability of the Nigerian deepwater oil fields. However, in assessing the prices, reference was made to Energy Information Administration (EIA, 2010). Figure 5.1 below depicts the historical trend of global oil prices which serves as a guide for the assumed prices for the study.

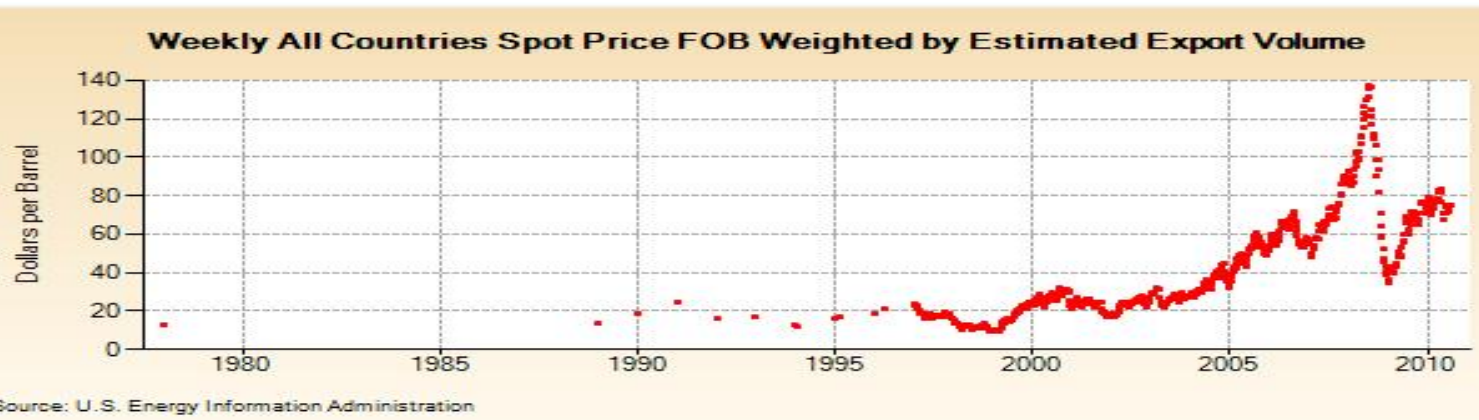

Figure 5.1. HISTORICAL TREND OF GLOBAL OIL PRICES

From the above graph, it could be discerned that in the last five years, US\$60/b is the least around which the oil prices hovered for a relatively longer time. The US $\$ 40 / b$ price was very momentary as depicted by the v-shaped recovery; hence was not adopted as the low price. Therefore, US\$60/b was assumed as the low price in the model while US $\$ 90 / \mathrm{b}$ and US $\$ 120 / \mathrm{b}$ were assumed as the medium and high prices, respectively. 


\subsubsection{Capital Expenditure (CAPEX)}

As in the case of oil reserves and production, reference was made to the capital costs of the main deepwater projects in Nigeria in arriving at the CAPEX for the hypothetical field. Table 5.2 below summarises the capital costs incurred in executing the main deepwater oil fields in Nigeria.

Table 5.2. SUMMARY OF CAPEX FOR MAJOR NIGERIA DEEPWATER FIELDS

\begin{tabular}{|c|c|c|c|c|c|}
\hline S/N & FIELDS & CAPEX (Billions of US\$) & Estimated Reserves (Million barrels) & Year of license award & Year of First Oil \\
\hline 1 & Bonga & 3.6 & 600 & 1993 & 2005 \\
\hline 2 & Erha\&Erha North & 3.5 & 1,000 & 1993 & 2006 \\
\hline 3 & Agbami & 7 & 800 & 1993 & 2008 \\
\hline 4 & Akpo & 5 & 620 & 1993 & 2009 \\
\hline
\end{tabular}

Source: NAPIMS, 2009/Rigzone, 2006/Chevron, 2010

From the foregoing, it took an average of at least twelve (12) years from exploration to the first oil. Also, Table 5.2 indicates that the average capital cost per barrel is about US\$6.5/b. Therefore, CAPEX of US\$3.9billion $(\$ 6.5 * 600 \mathrm{mb})$ was assumed in the analysis. However, in the absence of the explicit spending pattern of the CAPEX, an even-spending pattern was assumed for the 12 years exploration and development period. Hence, annual
CAPEX spending of US\$350million was assumed for each of the 12 years exploration and development period.

\subsubsection{Operating Expenses (OPEX)}

The British Petroleum (BP) historical statistical analysis data were employed as a guide in arriving at the model operating costs. Figure 5.2 shows a graphical representation of production cost history of major IOCs.

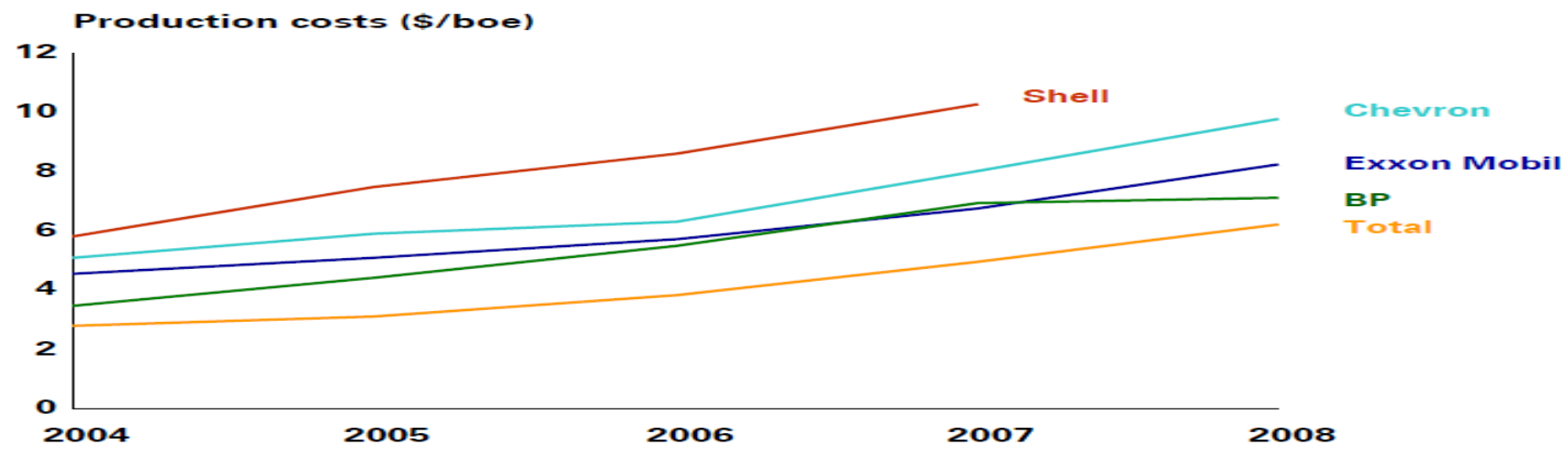

Figure 5.2. PRODUCTION COST HISTORY (Source: BP, 2009)

Following the trend of production cost from the above figure, coupled with the economic down turn recently experienced, an initial production cost of US\$8.5/b was assumed with exponential annual increment of $2 \%$.

\subsubsection{IOC Share of Profit Oil}

As earlier stated, an IOC is entitled to a share of the profit oil, in addition to the cost oil, which is intended to recoup the accumulated capital costs. However, and in any case, the share of profit oil is technically the same with the share of costs. Therefore, for the purpose of this research, a conservative rate of $40 \%$ was used as the investors' share of profit oil throughout.

\subsubsection{Discount Rate}

A discount rate of $15 \%$ was assumed. This is in line with many of the rates used in similar studies (Adenikinju and Oderinde, n.d; Kaiser and Pulsipher, 2004; World Bank, 2004).

\subsubsection{Rentals}

The PIB has provided for a maximum of $1000 \mathrm{~km}^{2}$ for a Petroleum Prospecting License (PPL) and Petroleum Mining Lease (PML) at the respective approved rates per $\mathrm{km}^{2}$. Further, the PIB provides for a maximum of 3 years for Petroleum Exploration License (PEL), 5 years for PPL, and the remaining development and production life of the field for PML. Therefore, the researcher assumed rent expenses of 3years for PEL, 5years for PPL, and 19years for PML.

\subsection{Analysis of Fiscal Neutrality, Stability, Flexibility and the Take}

The fiscal neutrality, stability, flexibility and the take are the qualities that determine the structure (system design) of the fiscal system (Okobi, 2009). The next four sub-sections will examine these qualities of fiscal system with a view to situating them in this study.

\subsubsection{Fiscal Neutrality}

In line with section 2.6.2 of chapter two, the PIB provisions are front-end loaded; that is, they are nonneutral or efficient. This is because the PIB proposes a large amount of non-profit related taxes. It proposes increased rents and royalties; the Nigerian Hydrocarbon Tax (NHT), Company Income Tax (CIT) and nonrecoverability of some costs. The NHT, which is partly revenue-based, is to replace the on-going Petroleum Profit Tax (PPT) of 50\% for deepwater offshore PSC operations. The CIT (30\% of net profit) on the other hand is introduced for the first time. Table 5.3 below gives a summary of some of the key PIB fiscal proposals. 
Table 5.3. Summary of Some Key PIB fiscal Proposals

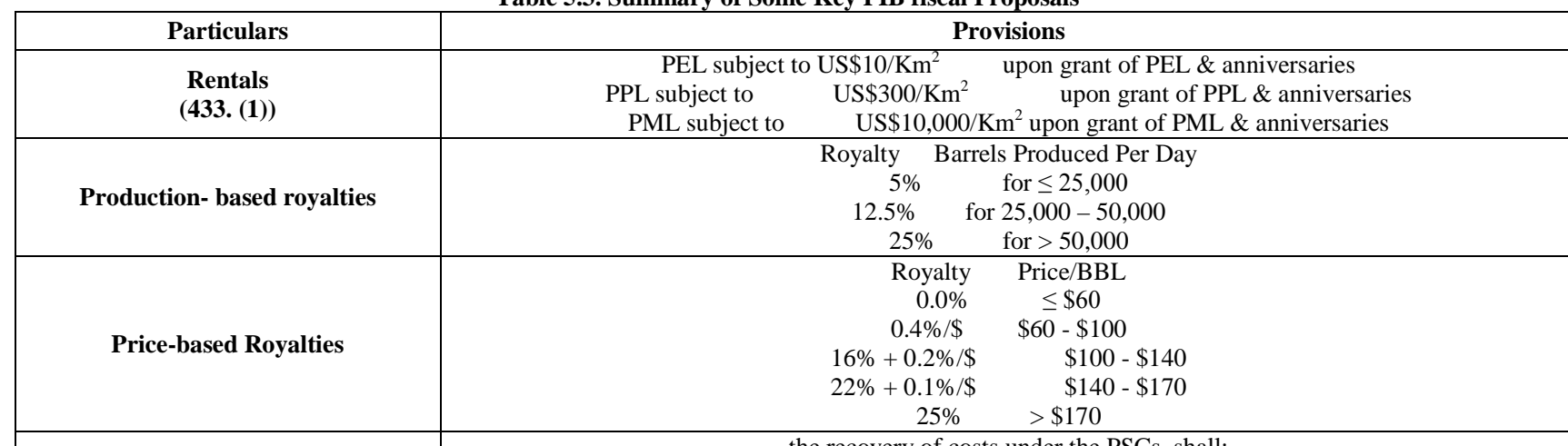

the recovery of costs under the PSCs, shall:

(a) Be limited to $80 \%$ of available oil and available gas or such lesser amount determined by the National Oil Company, and

500. (1)

(b) Such percentage may be subject to a sliding scale based on volume, price or other variables as established in the model contract. The higher of;

Nigerian Hydrocarbon Tax (NHT)

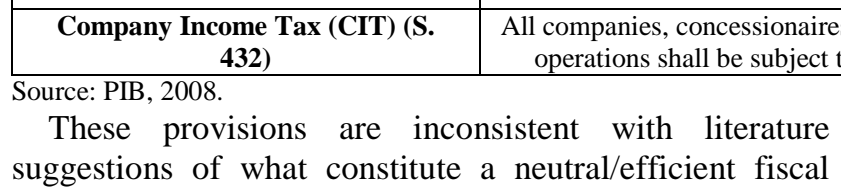
suggestions of what constitute a neutral/efficient fiscal
system. For example, Okobi (2009) argues that for a fiscal system's neutrality to exist government taxes/charges should be directed at only profits or economic rents. Therefore, these provisions of PIB cannot be adjudged neutral.

\subsubsection{Royalties and Rents}

Table 5.3 above shows that the PIB proposes rent payment and two sets of royalties to replace the current provision. These include rent payment based on size of acreage; production-based royalties of 5\%-25\% starting from 25,000 barrels per day (b/d) with a cap of 50,000b/d; and price-based royalties of $0 \%-25 \%$ starting with $\$ 60 / \mathrm{b}$ with a ceiling of $\$ 170 / \mathrm{b}$. Also, some costs incurred in the course of the petroleum operations are non-recoverable under the PIB terms. This, in line with section 2.6.2 of chapter two makes the proposed terms nonneutral/inefficient.

The front-end loaded system ensures that the HC captures adequate rents from the early stage of operations regardless of the projects' profitability (Akigbe, 2008). Therefore, the front-end loaded (non-neutral) system constitutes additional cost burden on the project which will eventually affect the extent of profitability. Hence, the inherent uncertainty in the non-neutral system will discourage IOCs from investing more in the sector.

\subsubsection{Nigerian Hydrocarbon Tax (NHT)}

The Petroleum Profit Tax (PPT) for deepwater offshore and frontier operations in Nigeria is currently put at 50\% of profit for PSC contracts (World Bank, 2004). However, the PIB proposes the NHT and CIT to replace the PPT. The proposed NHT rate for deepwater/frontier operations is $30 \%$ of total revenue less expenses. However, some costs are non-deductible for NHT purposes and only $80 \%$ of foreign expenses are deductible.

Meanwhile, expenses such as $20 \%$ of qualifying expenses incurred outside Nigeria; interest and financing
(443. (1)) (page 176) $2 \%$ of gross income - or

(454. (1)) (page 184) Assessable Tax which is;

(a) $50 \%$ for onshore and shallow water areas, and

(b) $30 \%$ for frontier and deepwater blocks

licensees, lessees, contractors and subcontractors involved in any petroleum

expenses; production and signature bonuses; and gas flaring penalties among other costs are not deductible for purposes of NHT (NNPC, 2009). Therefore, the tax base for the NHT is not fully profit-based since it excludes some qualifying expenditure. Therefore, despite being a profit-based tax, the NHT is not completely neutral tax either.

\subsubsection{Company Income Tax (CIT) and Withholding Tax on Dividends}

In addition to the NHT, the PIB proposes a Company Income Tax (CIT) of $30 \%$ on net profit. Withholding tax (WHT) of $10 \%$ is also proposed on dividend. Unlike in the case of the NHT, $100 \%$ of the relevant costs incurred are deductible for CIT purposes except for costs designated non-recoverable. However, the tax expense in respect of the NHT earlier charged is not an allowable deduction for CIT purposes. Furthermore, Signature bonuses and production bonuses are not cost recoverable or tax deductible (446(n) \& 496(2)). Therefore, like the NHT, the CIT also is not completely a profit-based tax since some relevant costs are non-allowable and nonrecoverable. Hence, the system is not very neutral.

\subsubsection{Discussion of Findings}

The foregoing evidence suggests that the proposed fiscal system in Nigeria is not neutral. In line with earlier discussions in Section 2.6.2, the proposed royalty rates, the NHT and the limitation on offshore expenditure by the PIB, renders the proposed system less neutral/efficient. None of the rents, royalties and taxes proposed by the PIB is completely free of one cost or the other. That is, none of the levies/taxes is completely profit-based. A system is said to be neutral if the taxes/levies are based on profit rather than revenue. A neutral system does not change the investment profitability index (Okobi, 2009).

However, due to the extent of uncertainties surrounding non-neutral/less-efficient fiscal systems, investors tend to be courteous with such systems (Akigbe, 2008). Therefore, IOCs in Nigeria would have to revisit their investment 
opportunities to reappraise the viability of the opportunities.

\subsubsection{Fiscal Stability}

The evidence from the assessment of fiscal stability visà-vis the discussions in section 2.6.1.2 suggest that the PIB proposed terms are not stable. The PIB does not have any fiscal stability clause to guard investors against unforeseen changes to financial assumptions of petroleum projects. Rather, the PIB contains some tight and openended provisions which assign the Minister the discretion to deal with such provisions among others. Some of the stability related concerns of the PIB include the following among others:

a. Section 260 proposes the creation of Incorporated Joint Ventures (IJVs) to take over the operations of the existing IOC-operated JVs (S. 260). The IJVs are to be owned and operated by parties in proportion to their interests before incorporation (S.260(a,d)). (NNPC has majority interest).

b. The NOC is to appoint majority of the members of the Board of Directors where it has majority interest (S.260(3)). Also, the Managing Director (MD) is to be appointed by the Board (S.260(9)).

From the inception of petroleum operations in Nigeria, the IOCs have been the operators of the main JV contracts. However, the JV incorporation, the proposed composition of the Board of Directors, and the appointment of the IJV's MD will threaten the smooth control of the JV operations by the IOCs. This proposal will dilute the IOCs operational control of the JVs. The Board which will have majority of NOC nominees may not take decisions with the speed and/or quality acceptable to the IOCs. Therefore, knowing these uncertainties, the IOCs will be skeptical to invest in such a highly risky venture.

c. Section 284(3) provides that in addition to the license renewal requirements of $\mathrm{S} .284(1,2)$, the renewal of Petroleum Mining Lease (PML) would be subject to additional conditions that may be set by the Minister in consultation with Directors General of the Directorate, the Inspectorate and the Agency.

d. Any PPL which is initially greater than ten parcels shall provide for the obligation to relinquish at least $50 \%$ of the original license upon expiration of the initial exploration period (S.285(1)). Further, the shape and size of the area to be retained and of the area to be relinquished/surrendered shall be as approved by the inspectorate (S.285(9)).

Clauses (c) and (d) above threaten license-holders' chances of retaining their license. The renewal process could be politicised. These provisions have accorded significant discretionary powers to the Minister. In addition to the express provisions for the renewal of PML licenses, the PIB requires the Minister to make consultations before deciding whether to renew the PML or not. This will undermine the openness and equity which the PIB sets out to achieve. Furthermore, the inspectorate is also assigned some discretion in respect of PPL relinquishment and decision on the shape and size of where to relinquish. These and other discretionary powers assigned to the NOC and the other Agencies will discourage IOCs from further investment in the upstream operations. e. Non-recoverability of signature and production bonuses (496(2)) and Overhead and general administrative expenditures incurred outside Nigeria (501(o)).

f. Ringfencing (497(1)): In case of production sharing contracts each contract area shall be ringfenced for the purposes of determining cost oil and profit oil.

The foregoing provision will certainly increase the amount of uncertainty in the industry. When costs legitimately incurred wholly and exclusively for the purpose of winning petroleum are non-recoverable, the IOCs (investors) will legitimately be discouraged in investing further in such an environment. The implication of this is that, in an adverse condition, the investor looses not only the profit but could also lose the capital or part there from. Furthermore, the ring fencing provision will negatively affect frontier operations. Frontier operations are in those areas whose hydrocarbon potentials are not proven. Frontier operations are more risky than those in proven areas.

\subsubsection{Discussion of Findings}

The foregoing evidence suggests that the proposed fiscal system is clouded with so many uncertainties; hence, not stable. The inherent uncertainties in the PIB proposals are threatening the relative stability hitherto enjoyed in the industry. For the first time in the Nigerian petroleum industry, the government has introduced radical changes that will give rise to increased revenue from royalties, rents, taxes and penalties among other things (Vanguard, 2009). However, the stability of investment was not given much attention.

Over the years, the Nigerian petroleum industry had experienced some stability except for the recent militant activities in the oil-rich Niger Delta. The Nigerian petroleum industry policies have been relatively stable. The main governing legislations of the industry (Petroleum Act 1969; PPT Act, 1959; and NNPC Act 1977) have not been materially altered from inception. In addition, the Memorandum of Understanding (MOU) between the NNPC and the IOCs guarantees a minimum return per barrel of oil for the IOCs (World Bank, 2005). This made Nigeria very attractive to the IOCs despite the militant attacks in the Niger Delta. Accordingly, Addax Petroleum (2009, p.3) submits that "the Addax story is a good story for Nigeria, and fiscal stability has been and continues to be a critical part of this success story”.

However, the above PIB proposals are a radical departure from what the laws are. The foregoing provisions create uncertainties which may deter an average investor from investing in the Nigerian oil industry. As such the industry operators led by the IOCs are contesting some of these PIB provisions which they claim proposes heavy and multiple taxes, acreage relinquishment and conferment of excess powers on the proposed regulatory agencies (Ugwuanyi, 2009).

For an upstream petroleum project to be bankable, lenders often consider the existence of a stable investment environment, stable/predictable fiscal regime, capacity to repay the loan, stability/certainty of cash flows, ability to pledge assets/future production, among other things. Considering the PIB proposals, some of the foregoing conditions may at best remain uncertain. Therefore, the bankability of the Nigerian upstream petroleum sector 
would be greatly impacted upon; hence, investment would be negatively affected.

\subsubsection{Fiscal Flexibility}

Evidence from this evaluation suggests that the PIB fiscal terms are fairly flexible. In line with modern fiscal systems design, some of the PIB proposals reflect progressive and flexible provisions. Some of the flexible provisions in the PIB include:

a. Rent payment is based on the type of license held at any point in time instead of a constant amount for all the licenses all the time. The PEL is subject to $\$ 10 / \mathrm{km}^{2}$, PPL is subject to $\$ 300 / \mathrm{km}^{2}$, and PML is subject to $\$ 10,000 / \mathrm{km}^{2}$. (see Table 5.3 above);

b. Proposed royalty rates are in sliding scales of production and prices (see Table 5.3 above);

c. Depreciation (500(4)): Contracts are to determine the treatment of recoverable costs including whether costs should be expensed or depreciated, the method of depreciation and pre-production costs; and

d. Profit oil (504(2)): The share of oil to the NOC would be stated in the contract and shall set out sliding scales resulting in a higher percentage.

The foregoing provisions are some of the main provisions that reflect flexibility in the proposed fiscal system. The royalties and rent provisions are set in a sliding scale which makes it a progressive one. Further, share of profit oil and treatment of depreciation are subjected to negotiations since they are to be determined by the contract agreement. Provisions for negotiation represent one of the most desirable flexibility tools by IOCs (Faruque, 2005). Therefore, the IOCs would always want more room for negotiations in some aspects of the contracts rather than complete legislative laws which are often non-negotiable.

\subsubsection{Discussion of Findings}

The foregoing evidence suggests a reasonable level of flexibility in the proposed fiscal system. The Nigerian petroleum fiscal system is a regressive system. That is, there is inverse relationship between government-take and increase in oil price and vice versa. The system is not designed to respond to changing market/industry realities. As such, IOCs (who operate the giant fields in Nigeria) take maximum advantage of the weakness in the system design to up their take whenever there is increase in oil price, at the expense of the HC.

However, the PIB has addressed this issue: royalties charges are now based on two sliding scales of oil prices and level of production. Table 5.3 above shows the breakdown of the proposed scale of royalty charges for deepwater/frontier operations.

However, notwithstanding the provision of the PIB in respect of the progressive royalty charges, it does not give operators much room for negotiation. The PIB is very comprehensive and covers many aspects of the industry. However, where there are no conclusive provisions, the final decisions are often within the jurisdiction of the Minister and the Directors General of the regulatory institutions. Whereas the omnibus nature of the PIB is commendable because of its relative transparency, the industry operators may not welcome it because it is watertight, therefore does not give much room for negotiations.
Nonetheless, there is nothing to suggest that the minimal provision for negotiation will discourage IOCs from investing.

\subsubsection{The Take}

The take analysis suggests that the deepwater oil operations under the PIB terms are viable. The result from the take analysis shows an average contractor-take of $10 \%$ from deepwater oil operations under the PIB terms. 10\% contractor-take in relation to Nigeria's hydrocarbon potentials suggests that the PIB economic terms provide very good investment opportunity for the IOCs.

Based on the provisions of the PIB, the computations below were carried out to give a rough estimate of what the take would be, for comparison with other HCs. The computations were made under the US\$60/b and US $\$ 120 / b$ to see the impact of price change on the take. However, these computations are based on average production royalty of $12.5 \%$ for giant deepwater fields, and US\$30/b as the full cycle cost per barrel in line with the hypothetical model computations. Seen from government and the contractors take from a barrel of oil at $\$ 60$ per barrel (/b). The $11 \%$ contractor-take implies that the contractor takes $11 \%$ of the oil after cost recovery. Contractor take is not the same as profit oil split because profit oil is inclusive of taxes while take is net of taxes. Therefore, the cost oil and taxes do not constitute part of the contractor take. The government take on the other hand constitutes all that is accruable to the government from a barrel of oil. These include royalties, profit oil, and taxes.

\subsubsection{Discussion of Findings}

The PIB proposal has shown an average of $90 \%$ government-take for the giant deepwater oil fields. The contractor-take is $10 \%$ at $\$ 120 / b$ oil price. However, as earlier discussed, the proposed system is a progressive one as the government-take increases with increase in production and oil prices. The progressiveness of the PIB terms is evidenced in the computations shows a government-take of $89 \%$ when oil price was $\$ 60 / b$, in contrast, a government-take of $90 \%$ when price rose to $\$ 120$; these results will be more revealing if quantities of production were used.

When compared with the take of other HCs, the PIB proposed government-take is high. However, it is not the highest. Figure 5.5 below shows a comparison of government-take in some selected HCs. The increased government-take will momentarily discourage investment at the initial stage but it will eventually reverse. Government-take will only retard investment to the extent it makes the investment unviable; but as long as the economic parameters (cash flow, NPV, PI, and IRR,) remain positive, the take may not be too important to the investor.

The foregoing analysis of take implies that after cost recovery, the government gets title to $90 \%$ of the total oil production through royalties, profit oil and taxes. Therefore, there is evidence to suggest that in addition to recovering its costs, the IOC would be entitled to $10 \%$ (100\%-90\%) of the profit oil net of taxes. Hence, considering Nigeria's hydrocarbons potentials, 10\% (net of costs and taxes) contractor take is a good deal. 


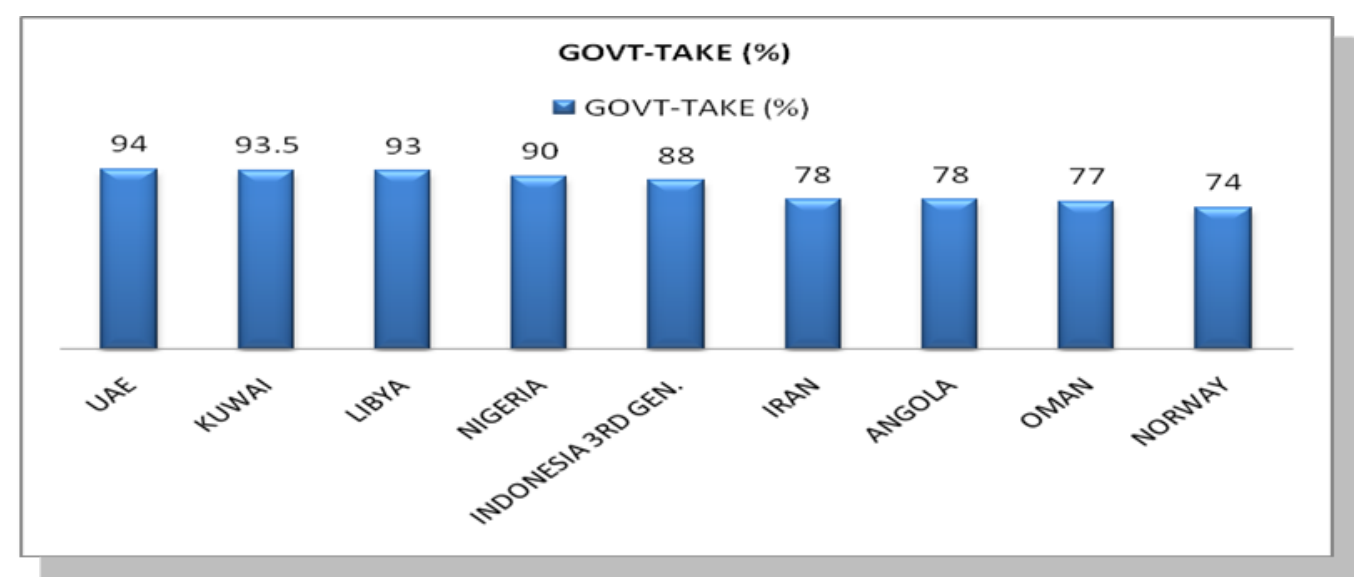

Figure 5.5. POST-PIB GOVERNMENT-TAKE COMPARISON WITH SELECTED HCS (Source: Author's computation/Van Meurs, (2008))

\subsection{Economic Indicators of Investment Viability}

The take is an important attribute of any petroleum fiscal system. However, whereas HCs see the governmenttake as an important measure of viability of a fiscal system, IOCs use, in addition to the attributes earlier discussed, the economic indicators of cash flow, NPV, PI and IRR to determine the absolute viability or otherwise of a project. Therefore, using hypothetical data (based on section 5.1 assumptions), the net cash flow (NCF), NPV, PI and IRR under the PIB fiscal terms were computed and the results are presented below. However, since the objective of this study is to determine the impact of the PIB on investment, the economic indicators computed are those of the IOCs who are the leading investors.

\subsubsection{Cash Flow Analysis}

Deepwater investment under the terms of the PIB yields positive net cash flow (NCF). Evidence from the hypothetical data analysis reveals positive NCF in the low, medium and high price scenarios. The assumed prices are $\$ 60, \$ 90$ and $\$ 120$ respectively. However, in all the scenarios, a recoverable oil reserve of 600million barrels was assumed. Positive NCF of US\$7.8Billion, US\$12.8Billion and US\$18.7Billion were recorded respectively. This implies that under the given assumptions, deepwater frontier projects are capable of paying-back themselves. The NCF test is the first test a project must pass before other appraisals for viability could be employed. The results as contained in table 5.4 below shows a positive correlation between oil price and the NCF. That is, the NCF increases as prices increase.

Accordingly, the positive NCF gives rise to a corresponding positive undiscounted rate of return. Undiscounted rate of return of $118 \%, 147 \%$, and $184 \%$ were respectively recorded for the $\$ 60 / \mathrm{b}, \$ 90 / \mathrm{b}$, and $\$ 120 / b$ price scenarios. The implication of the undiscounted rate of return is that at the price of $\$ 60 / \mathrm{b}$ under the PIB terms, an average deepwater oil field will yield $118 \%$ of the amount spent on it. That is, the project will pay-back its expenses and still have extra cash worth $18 \%$ of the total amount spent. This applies to the other scenarios too. However, the rate of return increases with increase in prices and/or production as evidenced in the results in the other cases. Table 5.4 below presents a summary of the NCF and the undiscounted rate of return under the different price scenarios.

Table 5.4. NET CASH FLOW AND RATES OF RETURN SUMMARY

\begin{tabular}{|c|c|c|c|}
\hline \multirow{2}{*}{ Details } & \multicolumn{3}{|c|}{ Assumed Scenarios and outcomes } \\
\cline { 2 - 4 } & Low & Medium & High \\
\hline $\begin{array}{c}\text { Recoverable Reserves } \\
\text { (Millions barrels) }\end{array}$ & $\underline{600}$ & $\underline{600}$ & $\underline{600}$ \\
\hline Oil prices (US\$/barrel) & $\underline{60}$ & $\underline{90}$ & $\underline{120}$ \\
\hline $\begin{array}{c}\text { Pre-tax undiscounted } \\
\text { NCF (billions \$) }\end{array}$ & $\mathbf{7 . 8}$ & $\mathbf{1 2 . 8}$ & $\mathbf{1 8 . 7}$ \\
\hline $\begin{array}{c}\text { Pre-tax undiscounted } \\
\text { rate of return (\%) }\end{array}$ & $\mathbf{1 1 8 \%}$ & $\mathbf{1 4 7 \%}$ & $\mathbf{1 8 4 \%}$ \\
\hline
\end{tabular}

Source: Author's computation.

The above cash flow analysis indicates that there is nothing to suggest that the deepwater oil fields in Nigeria under the PIB terms would be unviable. Therefore, there is evidence to suggest that unless under an unusually adverse condition, an average deepwater oil field in Nigeria under the PIB terms is viable under the cash flow test. However, further tests would be conducted to confirm this or otherwise.

\subsubsection{NPV Analysis}

Evidence from the NPV analysis also suggests that deepwater investment under the PIB terms in Nigeria is viable. Having passed the undiscounted NCF test, the projects were subjected to the NPV test under the same assumptions and scenarios. The NPV of \$0.2Billion, \$0.74Billion and \$1.36Billion were respectively achieved under the $\$ 60 / b, \$ 90 / b$ and $\$ 120 / b$ scenarios. Hence, under any of these scenarios, the petroleum project is viable since they have positive NPV. The positive NPV depicts the wealth generation potentials of the projects. Accordingly, the profitability index of the projects under the assumed scenarios shows that the projects are viable. The profitability index (PI) reveals that the discounted revenue from the projects exceeds the costs. For example, the PI implies that at $\$ 60 / \mathrm{b}$, the discounted revenue from the project will pay up its discounted costs with excess of $15 \%$ of the costs. In the same manner, at $\$ 90 / b$, the discounted revenue pays up all its costs with $47 \%$ extra. Ditto for the $\$ 120 / b$ price scenario. Table 5.5 below presents a summary of the pre-tax NPV and the profitability index of the model under the different scenarios. 
Table 5.5. NPV AND PROFITABILITY INDEX SUMMARY

\begin{tabular}{|c|c|c|c|}
\hline \multirow{2}{*}{ Details } & \multicolumn{3}{|c|}{ Assumed scenarios and outcomes } \\
\cline { 2 - 4 } & Low & Medium & High \\
\hline $\begin{array}{c}\text { Recoverable Reserves } \\
\text { (Millions barrels) }\end{array}$ & $\underline{600}$ & $\underline{600}$ & $\underline{600}$ \\
\hline Oil prices (US\$/barrel) & $\underline{60}$ & $\underline{90}$ & $\underline{120}$ \\
\hline Pre-tax NPV (billions US\$) & $\mathbf{0 . 2 0}$ & $\mathbf{0 . 7 4}$ & $\mathbf{1 . 3 6}$ \\
\hline Profitability Index (\%) & $\mathbf{1 1 5 \%}$ & $\mathbf{1 4 6 \%}$ & $\mathbf{1 7 8 \%}$ \\
\hline
\end{tabular}

Source: Author's computations.

The above evidence like in the cash flow analysis strongly shows the viability of the deepwater oil fields in Nigeria under the PIB terms. None of the results of the tests show any sign of negative return. Hence, further tests would be subsequently assessed for confirmation or otherwise.

\subsubsection{The Internal Rate of Return (IRR) Analysis}

The result from the IRR test also suggests that the PIB fiscal terms will not render the deepwater oil fields in Nigeria unviable. IRRs of $17 \%, 22 \%$ and $26 \%$ were obtained for the $\$ 60 / \mathrm{b}, \$ 90 / \mathrm{b}$ and $\$ 120 / \mathrm{b}$ price scenarios. Assuming a discount rate of $15 \%$, the projects are viable under the three scenarios. Whereas $15 \%$ discount rate was adopted for all the computations, the IRR was calculated to ascertain the true interest rates earned on the projects under the different scenarios. The IRR is the discount rate at which the project breaks even. The implication of the IRR is that unless the cost of capital exceeds the IRR, the project NPV will not be negative. That is, as long as the cost of capital does not exceed the IRR, the project will continue to generate wealth for its shareholders. However, any rate below these IRR rates would render the projects non-viable.

Therefore, at the assumed rate of $15 \%$ the projects are very viable. In the meantime, the IRR is a dynamic appraisal measure as depicted by table 5.6 below; it improves with improvement in market/industry conditions such as oil price and vice versa. For example, the table below shows how IRR increased from $17 \%$ when oil price was $\$ 60 / \mathrm{b}$ to $26 \%$ when oil price increased to $\$ 120 / \mathrm{b}$. Table 5.6 presents the summary of the discount rate and the IRR under the different scenarios.

Table 5.6. DISCOUNT RATE AND IRR

\begin{tabular}{|c|c|c|c|}
\hline \multirow{2}{*}{ Details } & \multicolumn{3}{|c|}{ Assumed scenarios and outcomes } \\
\hline & Low & Medium & High \\
\hline $\begin{array}{l}\text { Recoverable Reserves } \\
\text { (Millions barrels) }\end{array}$ & $\underline{600}$ & $\underline{600}$ & $\underline{600}$ \\
\hline Oil prices (US\$) & $\underline{60}$ & $\underline{90}$ & $\underline{120}$ \\
\hline Discount rate & $15 \%$ & $15 \%$ & $15 \%$ \\
\hline IRR & $17 \%$ & $22 \%$ & $26 \%$ \\
\hline
\end{tabular}

The IRR analysis presents a confirmation of the viability of the deepwater oil fields investments under the proposed PIB terms. The results of all the assumed scenarios produce IRRs greater than the cost of capital (15\%).

\section{Conclusion}

The purpose of this study was to evaluate the effect of the PIB-proposed fiscal terms on the upstream investment in the Nigerian petroleum industry. Therefore, document analysis of fiscal neutrality, stability and flexibility and the economic indicators of investment profitability were used in analyzing the questions raised. The results of the analysis show that the PIB-proposed fiscal terms may negatively affect the upstream investment in the Nigerian petroleum industry at least in the short run.

The computations of economic indicators of cash flow, NPV, and IRR show that the petroleum projects under the PIB terms are profitable. Similarly, fiscal system-design qualities of flexibility and take based on the PIB terms also show positive results. However, the lack of adequate fiscal neutrality and stability may create an uncertainty which could discourage investment in the upstream petroleum sector. As earlier submitted in the literature review, previous studies have extensively addressed a range of issues relating to the dynamics of petroleum fiscal systems and investment in different countries, including Nigeria. However, the effect of PIB on investment in the Nigerian petroleum sector was not addressed. This research has accordingly addressed the effect of the PIB-proposed fiscal terms on investment in the Nigerian upstream petroleum sector. Therefore, it adds to the body of literature in this area.

Nevertheless, the researcher acknowledges that the quantitative process employed in this analysis appears piecemeal, involves large amount of work and has restrictions common to geometrical and tabular presentation of multidimensional data. It does not communicate the effects of the individual fiscal terms proposed by the PIB due to data limitations. Therefore, in addition to the overall effect, the effect of the individual PIB-proposed fiscal terms on upstream investment could be further investigated using a more robust (regression) model with time-series data. However, this would be more feasible after the implementation of the PIB proposals.

In conclusion, the PIB represents a single transparent proposed legislation which exhaustively addresses all issues of the Nigerian petroleum industry. The economic indicators of upstream investment under the PIB terms reveal profitable results. Also, the non-neutrality of the PIB fiscal terms may not be a major concern because it is often the general practice in the industry; that majority of petroleum fiscal systems are non-neutral. However, profitability without stability is not adequate to attract investment. Fiscal stability is required to create and sustain investor confidence. Therefore, to encourage investment in the upstream sector, the fiscal stability concerns in the PIB need to be readdressed.

\section{References}

[1] Abdulkarim, R. 2009. The Fiscal Tools in the UK Petroleum Licensing: How did the UK Attract Investments and What are the Effects of Changing Terms? The Centre for Energy, Petroleum and Mineral Law and Policy Annual Review. June 2009. pp.24.

[2] Addax Petroleum Corporation, 2009. Memorandum on the Review of the Petroleum Industry Bill. Presented at: The House of Representative Joint Committee on the Petroleum Industry Bill 2009, Abuja, 30 July.

[3] Adenikinju, A. and Oderinde, L.O. [no date]. Economics of Offshore Oil Investment Projects and Production Sharing Contracts: A Meta Modeling Analysis. [Online]. Available from: http://www.africametrics.org/documents/conference09/papers/Ade nikinju_Oderinde.pdf [Accessed 11 May 2010].

[4] Akhibge, I.J.O. 2008. How attractive is the Nigerian Fiscal Regime, which is intended to Promote Investment in Marginal 
Field Development? The Centre for Energy, Petroleum and Mineral Law and Policy Annual Review. June 2008. pp.11.

[5] Al-Attar, A. and Alomair, O. 2005. Evaluation of Upstream Petroleum Agreements and Exploration and Production costs. OPEC Review. 29(4). pp.243-266.

[6] Ameh, M.O. 2006. The Shift from Joint Operating Agreement to Production Sharing Contracts in the Nigerian Oil and Gas Industry: Any Benefit for the Players? The Centre for Energy, Petroleum and Mineral Law and Policy Annual Review. February 2007. pp.27.

[7] Blake, A.J and Roberts, M.C. 2006. Comparing Petroleum Fiscal Regimes under Oil Price Uncertainty. Resource Policy.31(2). pp.95-105.

[8] Brock, H.R., Carnes, M.Z., and Justice, R. 2007. PetroleumAccounting: Principles, Procedures, \& Issues. $6^{\text {th }}$ ed. Texas: Professional Development Institute

[9] Energy Information administration. 2010. Crude Oil Production. [Online]. Available from: http://www.eia.doe.gov/neic/infosheets/crudeproduction.html [Accessed 01 August 2010]

[10] Energy Information Administration, 2010. Nigeria: Oil. [Online]. Available from: http://www.eia.doe.gov/cabs/Nigeria/Oil.html [Accessed 20 July 2010]

[11] Energy Information Administration. 2010. Short-Term Energy Outlook. [Online]. Available from: http://useconomy.about.com/gi/o.htm?zi=1/XJ\&zTi=1\&sdn=usec onomy\&cdn=newsissues\&tm=35\&gps=671_504_1276_579\&f=10 $\& s u=p 649.3 .336 . i p \_\& t t=11 \& b t=0 \& b t s=0 \& z u=h t t p \% 3 A / / w w w . e i$ a.doe.gov/emeu/steo/pub/contents.html [Accessed 02 August 2010].

[12] Faruque, A. A. 2005. Stability in Petroleum Contracts: Rhetoric and Reality: Lessons from the Experiences of Selected Developing Countries and Economies in Transition (1980 - 2002). Thesis submitted to: The Centre for Energgy, Petroleum and Mineral Law and Policy, University of Dundee, Dundee, August 2005.

[13] Fattouh, B. and Darbouche, H. 2010. North African oil and foreign investment in changing market conditions. Energy Policy. 38(2) p.1119-1129.

[14] Fattouh, B. and Mabro, R. 2006. The Investment Challenge. In: Mabro, R. ed. Oil in the $21^{\text {st }}$ Century: Issues, Challenges and Opportunities. New York: Oxford University Press. pp.101-127

[15] Financial Times, 2010. New Bill Puts Nigeria’s Deepwater Oil industry on Hold. [Online]. Available from: http://blogs.ft.com/beyond-brics/2010/06/17/new-bill-putsnigerias-deepwater-oil-industry-on-hold/ [Accessed 05 August 2010].

[16] GersonLehrman Group, 2010. A Quick Look at Deepwate Statistics for 568 Oilfields. [Online]. Available for: http://www.glgroup.com/News/A-quick-look-at-deepwaterstatistics-for-568-oilfields-49026.html[Accessed 05 August 2010].

[17] Gidado, M. M. 1999. Petroleum Development Contracts with Multinational Oil Firms: The Nigerian Experience. Maiduguri: Ed-Linform Services.

[18] Iledare, O.O. 2004.Analyzing the Impact of Petroleum Fiscal Arrangements and Contract Terms on Petroleum E\&P Economics and the Host Government Take. In: Proceedings of the 2004 Society for Petroleum Engineers' Nigerian Annual Conference and Exhibition, Abuja August 2-4 2004.

[19] Iledare, O.O. and Kaiser, M. 2006. Profitability of Deepwater Petroleum Leases: Emipirical Evidence from the U.S. Gulf of Mexico Offshore Region. [Online]. Available from: http://www.onepetro.org/mslib/servlet/onepetropreview?id=SPE116602-MS\&soc=SPE [Accessed 09 May 2010].
[20] Johnston, D. 2003. International Exploration Economics, Risk, and Contract Analysis. Oklahoma: Penn Well Corporation.

[21] Kaiser, M.J and Pulsipher, A.G. 2004. Fiscal System Analysis: Concessionary and Contractual Systems used in Offshore Petroleum Arrangements. Louisiana: Centre for Energy Studies.

[22] KALEJAYE, K. (2014) Non-passage of PIB threatens Nigeria content development. Available at: http://www.vanguardngr.com/2014/04/non-passage-pib-threatensnigeria-content-development/\#sthash.RgjIu0KS.dpuf.

[23] Kemp, A.G. 1992. Development Risks and Petroleum Fiscal Systems: a Comparative Study of the UK, Norway, Denmark and the Netherlands. The Energy Journal. [Online]. Available from: http://www.allbusiness.com/utilities/341119-1.html [Accessed 7 May 2010].

[24] Lukman, R. 2009. Keynote Address by the Honourable Minister of Petroleum Resources on the Proposed Petroleum Industry Bill (PIB). Abuja, 16 July

[25] Mabro, R. 2003. Setting the Scene. OPEC Review. 27(3) pp.18790.

[26] Mahmud, M. and Russel, A. 2002. Evidence that the terms of Petroleum Contracts Influence the Rate of Development of Oil Fields. OPEC Review. 26(1), p.21-44.

[27] Okobi, N. 2009. To What Extent will Alberta's New Fiscal Regime Attract Future Exploitation of Tar Sand? The Centre for Energy, Petroleum and Mineral Law and Policy Annual Review. June 2009. pp.29.

[28] Pongsiri, N. Partnerships in Oil and Gas Production-Sharing Contracts. The International Journal of Public Sector Management. 17(5). pp.431-442.

[29] Shell Nigeria (SPDC), 2010. PIB: No Further Investment in Nigeria, says IOCs. BusinessDay newspaper, March 2010. [Online]. Available from:

http://www.businessdayonline.com/index.php?option=com_conten t\&view=article\&id=9150:pib-no-further-investment-in-nigeriasay-iocs\&catid=1:latest-news\&Itemid=18 [Accessed 10 March 2010].

[30] The Federal Government of Nigeria, 2008. Petroleum Industry Bill. [Online]. Available form:http://www.nnpcgroup.com/pib/petIndsBillDocs/PIBDrapftB ill2008.pdf [Accessed 20 January 2010].

[31] Ugwuanyi, E. 2009. Petroleum Industry Bill stirs controversy. The Nation [Online] Aug 27. Available from: http://thenationonlineng.net/web2/articles/23267/1/PetroleumIndustry-Bill-stirs-controversy/Page1.html [Accessed 15 July 2010].

[32] Van der Veer, J. 2005. What is the International Oil Company of Future Going to Look Like? [Online]. Available from: http://www.shell.com/static/mediaen/downloads/speeches/jvdv_oilsummb.pdf [Accessed ].

[33] Vanguard newspaper, 2009. Nigeria: PIB Introduces New Fiscal Regime. [Online] Aug 31. Available from: http://allafrica.com/stories/200908311634.html [Accessed 15 June 2010].

[34] Van Meurs, P. 2008. Government Take and Petroleum Fiscal Regimes. [Online]. Available from: http://www.krg.org/uploads/documents/Government_Take_and_P etroleum_Fiscal_Regimes_2008_06_30_h14m7s53.doc [Accessed 15 June 2010].

[35] Zanoyan, V. 2004. The Oil Investment Climate. Middle East Economic Survey. 47(26). 